STAGING PERSONHOOD 



\section{Staging Personhood}

Costuming in Early Qing Drama

\section{Guojun Wang}


This publication was made possible in part by an award from the James P. Geiss and Margaret Y. Hsu Foundation and an Association for Asian Studies First Book Subvention award.

Material for the introduction, chapter 3, and appendixes of this book first appeared in Guojun Wang, "Absent Presence: Costuming and Identity in the Qing Drama A Ten-Thousand Li Reunion," Harvard Journal of Asiatic Studies 79, no. 1 (2019). Reprinted by permission of the author and the publisher.

Columbia University Press

Publishers Since 1893

New York Chichester, West Sussex

cup.columbia.edu

Copyright $\odot 2020$ Columbia University Press

All rights reserved

Library of Congress Cataloging-in-Publication Data

Names: Wang, Guojun, 1982- author. | Wang, Guojun, 1982- Sartorial spectacle.

Title: Staging personhood : costuming in early Qing drama / Guojun Wang.

Description: New York : Columbia University Press, [2020] | Revision of author's thesis:

Sartorial spectacle : clothing, identity, and the state in early Qing drama. |

Includes bibliographical references and index.

Identifiers: LCCN 2019033435 (print) | LCCN 2019033436 (ebook) |

ISBN 9780231191906 (cloth) | ISBN 9780231549578 (ebook)

Subjects: LCSH: Costume-China-History-Ming-Qing dynasties, 1368-1912. |

Clothing and dress-China-History-Ming-Qing dynasties, 1368-1912. |

Clothing and dress-Social aspects-China. | Theater-China-History-17th century. |

Theater and society-China.

Classification: LCC GT1555.W2776 2020 (print) | LCC GT1555 (ebook) |

DDC 391.00951-dc23

LC record available at https://lccn.loc.gov/2019033435

LC ebook record available at https://lccn.loc.gov/2019033436

Columbia University Press books are printed on permanent and durable acid-free paper. Printed in the United States of America

Cover image: Anonymous, Wanshou tu 萬壽圖, detail of a scroll, color on silk, 1799. Palace Museum, Beijing. Reprinted in Putian tongqing: Qingdai wanshou shengdian, ed. Gugong Bowuyuan (Beijing: Gugong chubanshe, 2015). 
For Pengfei 
